Working paper

(do not cite without the permission of the corresponding author)

\title{
A Socio-material Perspective on Temporal Work: \\ Practice Breakdowns during Strategic Upheaval
}

\author{
Raymond Loohuis \& Michel Ehrenhard \\ University of Twente, Enschede, the Netherlands
}

Corresponding author: r.p.a.loohuis@utwente.nl

This paper was presented at the Academy of Management (AOM) conference in Philadelphia, Pennsylvania, USA in August 2014 


\begin{abstract}
How does a breakdown in ongoing organizational practices produce temporal work? While the mainstream literature mostly assumes that strategic change is a purposeful and futureoriented process, recent work demonstrates that strategy making requires temporal work on the part of actors to make strong interpretative links across the past, present, and future to reestablish strategic settlements once existing ones have broken down. The purpose of this paper is to extend the concept of temporal work by approaching it from a socio-material point of view. We draw on a field study lasting for three years at six agricultural nonprofits risking to lose significant parts of their revenues due to substantially changing subsidy priorities set by the government, which causes a strategic upheaval in their field. We examine how the socio-material structures underlying the practices of these associations break down and shape temporal work when actors are facing the upcoming changes. More specifically, we examine in detail how variations in socio-material structures produce different levels of temporal work and with what result for practice alignment and development. Our study revealed that differences in socio-material structures lead to different levels of temporal work, namely low, moderate or substantial. Low temporal work implied that actors re-produce ongoing practice and postpone actions to change. Moderate implied a re-alignment of practices in the present in anticipation of the future. Substantial temporal work resulted into a drift as actors could not see how to align future demands in ongoing practice. Our findings reveal that different socio-material structures produce different levels of temporal work in practices of associations that are nonetheless, active within the same institutional field. We contribute to existing research interested in the practices of strategy making but also to literature on radical and institutional change by demonstrating how socio-material dimensions in relation to human agency matter in understanding issues of inertia as well as change of organizational practices in relation to environmental change.
\end{abstract}

Key words: Socio-materiality, Practice-driven, Breakdowns, Temporal work, Change, Nonprofits

\title{
Introduction
}

How actors make sense of an ambiguous and uncertain environment and go on to develop strategy is an important theme in organizational scholarship (Garud, Kumaraswamy, \& Karnøe, 2010; Kaplan, 2008; Kaplan \& Orlikowski, 2012; Stensaker \& Falkenberg, 2007). The Strategy-as-Practice approach (S-as-P) emerged and aimed to shift the focus from organizations and strategies to strategists and strategizing (Jarzabkowski, 2005; Whittington, 1996). In doing so, the S-as-P approach adopts a 'sociological eye' by directing the focus on what actors do with things during strategy making. As such, the S-as-P shows how strategy making is a social practice of organized human activity (Whittington, 2006).Yet despite its appreciation of the micro-activities of social and historically embedded actors, the S-as-P 
approach tends to adhere to the idea that strategy actors themselves are in charge of strategy processes and act purposefully towards pursuing goals. Because of this focus, scholars have argued that the $\mathrm{S}$-as-P tends to follow an individualist social ontology by giving primacy to strategy actors, rather than the social practice itself (Chia, 2004; Chia \& MacKay, 2007; Sandberg \& Dall'Alba, 2009). Also Vaara and Whittington (2012) propose that the social practices of strategy making should be taken more seriously by looking at human agency as part of practice, emergence, and materiality (see also Balogun, Jacobs, Jarzabkowski, Mantere, \& Vaara, 2013). Indeed, materiality matters and therefore should be included in organizational analysis as endorsed by scholars interested in the relationship between work, technology, and organization (Orlikowski, 2007; Orlikowski \& Scott, 2009).

On the part of human agency, Kaplan and Orlikowski (2012) demonstrated how strategic change require actors to make strong interpretative links to the past, present, and future to move forward when exposed to a breakdown of existing strategic settlements. So rather than solely by accurate foresight and careful planning, their study revealed that strategic change requires actors to re-interpret their temporal orientations in order to re-settle on a new strategic account. Therefore, temporal work can be considered as an important interpretive process underlying agency that produces subsequent strategic change. Nevertheless, while the concept of temporal work is sensitive to the struggles of situated actors in practice, there seems to be a cognitive overtone in a sense that change is due to the re-construction of the past, present, and future. In other words, it is unclear how temporal work and subsequent change comes about from the positions of actors in their structurally embedded contexts. Informed by Chia and Holt (2006) notion of a 'dwelling mode' and a 'building mode' of existence involved in strategy making, we examine how temporal work develops from a more fundamental dwelling mode of existence. A dwelling mode of existence presupposes that actors are engaged in socio-material practices and realize ends without being thematically aware of that practice. In turn, a building mode of existence reflects purposeful behavior and thought that occurs after actors experience a breakdown in their socio-material practices. We understand temporal work as a building mode of existence that allow actors to deliberately re-construct the past, present, and future on the background of their involvement in socio-material practices. The approach taken in this paper reflects what Ericson (2013:12) describes as, "an understanding and interpretation that ontologically pertains to existential entwinement in relation to live activity in time". To understand how actors relate to their socio-material practice, we adopt a practice perspective that understands a social practice as a nexus of organized human activities and material arrangements (Schatzki, 2002). This 
approach allows us to see how variations of socio-material dimensions such as technology in use (tools, equipment, etc) that actors use to attain practice goals, the standards of excellence they draw on, the raw materials they use and produce, but also how practice history and the maintenance of practice values and norms coherently relate to each other and mediated through shared understandings. Our research question is: how do variations in organizational socio-material structures underlying ongoing practices shape different levels of temporal work and what are the implications for strategic change and practice development?

Our study is structured around an event with system disturbing potential (Barley \& Tolbert, 1997). Based on a multiple case study design (Miles \& Huberman, 1994), we studied temporal work at six agricultural nonprofits in the eastern part of the Netherlands for over three and a half years. These associations - all concerned with preserving the ecological and cultural value of their local landscapes - draw on specific socio-material practices to conduct landscape work which is paid for from using both national and EU subsidies. Though this was the case for a long time, in 2015 these associations will have to cope with drastic change in the European and national selective subsidy regimes. Both bodies demand that agricultural associations in general, adopt both professional standards and entrepreneurial practices that lower their reliance on subsidies. The system disturbing potential in our case is that these changing requirements unleashed a breakdown in the socio-material structures since actors encountered difficulties anticipating on the expected changes in relation to their ongoing practices.

The insights that emerged from our study is that variations in the socio-material structures underlying each associations' practice produced different levels of temporal work, with each having specific outcomes for change. A low level of temporal work implied that actors maintain ongoing practice and postpone actions to change. In other words, the past, present, and future remained coherently linked. This was the case at two associations. Here we observed that actors draw on a rich practice history, multiple activities, and are strongly embedded in their local operating context. At two other associations, we observed moderate temporal work which implied that actors re-aligned their practice in anticipation of the upcoming changes. Actors were able to re-construct the past, present, and the future successfully. At these two associations, we observed that actors draw on a rich practice history, operate in an environment with abundant natural resources, and focused on a continuous improvement of their specialist skills, technology and standards of excellence. Finally, a substantial level of temporal work was observed at two other associations. Actors encountered significant difficulties in re-constructing the past, present, and future since they 
could not see how their current practice could match the expected future changes. These associations both share a lack of sufficient resources to exploit entrepreneurial practices and have a short, and in part, interrupted, practice history. In addition, one association encountered constraints of the older generation board members to anticipate on the future during our research involvement.

We make several theoretical contributions with this study. First we show how temporal work emerges from actors' existential situations and how variations in the socio-material structures shape different levels of temporal work. In doing so, we extend current views on the emergence of intentionality and practice development (Lounsbury \& Crumley, 2007; Stensaker \& Falkenberg, 2007). Second, our research contributes to S-as-P scholarship by responding to their call how strategy making can be understood from a socio-material point of view (Balogun et al., 2013). Finally, we contribute to the institutional entrepreneurship literature interested in human agency in relation to the transformation of fields (Dorado, 2005; Lawrence, Suddaby, \& Leca, 2011). We show that the "logic of action" (Dorado, 2005) of individual actors in a given field is predominantly shaped the structure of their socio-material practices, rather than through field characteristics.

We structured the remainder of this paper as follows. In the next section we develop a framework for understanding temporal work from a socio-material perspective. We then describe the research methods. This leads to a presentation of the level temporal work at the six agricultural associations in relation to the socio-material structures of each association. After that, we cross-examine the cases and propose three different levels of temporal work in relation to outcomes for strategic change and practice development. In the final section, we discuss our findings and offer implications for further research. We conclude this paper in the final section.

\section{Theory}

Business actors are frequently confronted with ambiguity and uncertainty when looking into the future. Scholars have argued that actors use framing practices as a mean to make sense the future and reduce ambiguous information and environmental uncertainties (Gioia \& Thomas, 1996; Kaplan, 2008). Particularly sense-making approaches (Weick, 1995) make clear that actors also make interpretative links in time either through retrospective rationalization (Balogun \& Johnson, 2004; Gavetti \& Levinthal, 2000) or by future perfect thinking (Weick, 1979). In other words, dealing with challenges require cognitive re- 
orientations of time to move forward. Sense-making particularly occurs when there is a gap between actors' expectations and experience, for instance by suprise (Louis, 1980). When this happens, actors start to act in a more thoughtful way (Weick \& Roberts, 1993; Weick, Sutcliffe, \& Obstfeld, 2008). Recently, Kaplan \& Orlikowski (2013) demonstrated how actors engage in so-called temporal work once existing strategic settlements break down. Temporal work entails the interpretative processes through which actors re-constructs links across the past, present, and future when confronted with a breakdown of their current understandings. Their study showed that actors can re-construct links between the past, present, and future once they consider them as coherent, plausible, and acceptable leading into concrete strategic choice and action. In case they failed to do so, further interpretative breakdowns occurred. Therefore, temporal work can be considered as a distinctive analytical category of agency that can produce strategic action and change (see also Emirbayer \& Mische, 1998). Indeed, Kaplan \& Orlikowski (2013) argue that "temporal work is a central practice of strategy making"'(p 26). Nevertheless, while their concept is sensitive to the struggles of situated actors (Suchman, 1987), we suggest that temporal work is primarily occupied with the cognitive re-orientations of time itself, rather than how such re-orientations are shaped by the engagement of actors in their structural contexts. In other words, it is unclear how temporal work, and thus agency, is shaped by actors' existential situations. Recently, S-as-P scholars increasingly have advocated to adopt a so called 'life-world perspective' when studying strategy making (Chia \& MacKay, 2007; Sandberg \& Dall'Alba, 2009). Such an approach brings "to the fore the manner in which practice is constituted through our entwinement with others and things in our world" (Sandberg \& Dall'Alba, 2009:1349).

In this paper, we extend the concept of temporal work from the perspective that the reconstruction of time is preceded by actors' entwinement in socio-material practices (Sandberg \& Tsoukas, 2011). Such a perspective give primacy to the idea that temporal work is a derivate mode of agency that develops from a more fundamental mode. The difference between these modes of agency can also be understood as a building and a dwelling mode of existence (Chia \& Holt, 2006). Such a perspective presupposes that the cognitive reorientations of actors across the past, present, and future that enable actors to more forward cannot be separated from their existential situations in everyday practice (Ericson, 2013).

The remainder of this section is structured as follows: we first discuss how we can understand the engagement of actors in everyday socio-material practices. After that, we introduce the concept of temporal work as a derivate mode of agency that emerges from a more fundamental mode when actors are confronted with practice breakdowns. 


\section{Engagement of actors in socio-material practices}

Scholars note that matters, like objects, machines, resources, artifacts, desks, matters in organizations (Carlile, Nicolini, Langley, \& Tsoukas, 2013; Feldman, 2004; Orlikowski, 2007). Whenever materiality becomes integral to human activities and relations, it can be understood as sociomaterial (Orlikowski, 2007; Orlikowski \& Scott, 2009; Sandberg \& Tsoukas, 2011). Therefore, objects of all kind are essential to human activity and organizational outcomes since actors draw on them and use them for some purpose. Orlikowski and Scott (2009) identified three ontologically different typologies of social material relationships. The first type views the relationship between social and material dimensions as consisting of discrete independent units which causally relate to each other. In this type, human actors and objects relate to each other but remain, in the end, self-contained entities. The second type considers social and material dimensions as independent entities yet they shape each other through ongoing interaction. The third type sees social and material dimensions as sociomaterial assemblages (without a hyphen). They are so fused together that they can be considered as "agencies that have so thoroughly saturated each other that previously taken-for-granted boundaries are dissolved"(Orlikowski and Scott, 2009:455). As a result, the third type requires an acceptance that materiality is so implicit in everyday activities and relations that the boundaries between humans and objects are dissolved (see also Pickering, 1993).

A prominent body of literature that particularly draws on the third type is actornetwork-theory (ANT). ANT permits to see how technological artifacts are treated as equal members in a network of other human-and non-human agencies which are provisionally configured to produce effects (Callon, 1986; Latour, 2005; Law, 1994). At the core of an ANT is a relational ontology, one that flattens out conventional dualisms and conceives of agency as distributed across social and material elements (Latour, 2005). Yet, rather than explaining it stability, ANT is primarily occupied with the emergence and dynamics of sociomaterial configurations. Or as Rip (2010:xx) remarks; “ANT prefers to address changing, fluid, "hot" situations". Recently, Gehman, Treviño, \& Garud (2013) applied an ANT perspective to study empirically how values, such as honor codes, materialize into organizational practices through a process termed, values work. Rather than seeing values in abstract terms or culturally defined, Gehman et al. (2013) describe the processes through 
which values become entangled into socio-material practices across individuals and collectives.

Practice theory and specifically what is referred to as the 'practice turn' (Schatzki, Knorr-Cetina, \& Von Savigny, 2001) addresses how social practices are composed of both social as well as material relationships. According to Schatzki et al. (2001:2), "practice theorists conceives of practices as embodied, materially mediated arrays of human activity centrally organized around shared practical understanding". Whereas ANT is primarily concerned with emergence and change of socio-material configurations and its insistence of a full symmetry between social and material dimensions (Law, 1994), a practice approach is mainly occupied with understanding how actors routinely engage in social activities in conjunction with things that are given thematic coherence by shared meanings and understandings of actors (Schatzki 2002). Therefore, a practice is first of all stable because it carries on the normative understandings in terms of what actors "ought to realize or ones that is acceptable for them to do so" Schatzki (2002:81-85). As a result, the development or transformation of a practice is challenged by the normative understanding of actors regarding the means-ends relationships of a practice, pointing to the teleological structure of a practice (Schatki, 2002). Furthermore, practices can also be considered as temporal structures since they defined by their teleological end points as well as its practice memory (Schatzki, 2006). In other words, actors draw on prior practice experience when realizing practice ends. Orlikowski and Yates (2002) offered a practice lens to understand how actors use and create time in social practices, oftentimes in a taken-for-granted fashion. An important feature of practice theory is that it places mind, body, things, process and agency on the same ontological footing. In other words, the practice itself is the smallest unit of analysis (Reckwitz, 2002). Therefore, human actors are subordinated to practice yet embody it, rather than in charge of it (Chia \& MacKay, 2007). Furthermore, human actors are usually routinely involved in practices, that is, without being thematically aware of that practice. Or as Swidler (2001:75) notes: “practice theory moves the level of sociological attention 'down' from conscious ideas and values to the physical and the habitual". This kind of engagement of actors in practices is also indicated by the term 'absorbed coping', a mode of existence that allow actors to routinely deal with things like equipment, resources, or technology, to realize practice goals without the need for having a thematic awareness of the practice itself (Dreyfus, 1991). This mode is also indicated as a 'dwelling mode' of existence (Chia \& Holt, 2006) and resembles Bourdieu's (1990) idea of 'habitus' (Bourdieu, 1990), and also Gidden's conception of practical consciousness in routine practices (Giddens, 1984). These viewpoints 
on the position of cognition in everyday life is to a large extent informed by philosophers such as Heidegger (1962) or (Wittgenstein, 2010).

In summary, a practice driven approach enables us to see how it is that actors draw on shared understandings about things, others and time to realize practice ends without the need for a thematic awareness of that practice as long they remain consider them as coherent.

\section{Practice breakdowns and temporal work}

While actors usually realize practice ends without thematically aware of their practice, there are moments in which actors shift to a more thoughtful mode of existence. Or in the terminology of Heidegger: mental content arises when the availableness of ready-to-hand coping breaks down and attention shifts to unready-to-hand, or to a present-at-hand occurentness when actors can no longer see how to move further (Dreyfus, 1991). Unreadyto-hand, happens when something does not work properly, is missing, or obstructs ongoing practice. In such situations, the relationship between practice-ends and the practice itself is temporarily interrupted and shortly open for thought and action (Sandberg \& Tsoukas, 2011). In that case, actors must pay attention by articulating their concerns and do something in order to continue their practice. In case of a present-at-hand situation, the constitutive assignment between cognition, activity, and goals is completely broken (Patriotta, 2003). In that case, actors either engage in pure theoretical reflection and start to identify aspects of their practice as mere objects with isolated properties, or helplessly stare (Dreyfus, 1991). Hence, there are distinctive kind of breakdowns, ranging from mild to a complete breakdown with each having distinctive consequences to the degree of scope that actors have in their practice (Yanow \& Tsoukas, 2009). This shift to a elaborated mode of existence is reflected in the distinction made by Chia and Holt (2006) between a dwelling mode and a building mode of existence. While a dwelling mode reflects the everyday engagement of actors in socio-material practices, a building mode echoes the way actors engage in a more thoughtful way of being once their practice is interrupted.

Given these insights, we suggest that temporal work is a specified form of a building mode of existence, since it addresses how actors make sense of the past, present, and future of their practice once settled strategic accounts are no longer tenable. A view on temporal work understood from a socio-material perspective highlights the ability of actors to re-construct the past, present, and future in relation to the socio-temporal structure of their practice. Hence, whenever actors succeed in re-constructing links across the past, present, and future, it is because they succeeded in negotiating the social-material relationships underlying their 
practice anew when these were momentarily brought into view. If actors fail to negotiate these relations, they also fail to re-construct links across these time dimensions in relation to their practice, which implies that further interpretative breakdowns occur. The level of temporal work, that is, the extent to which actors make interpretative links across time, is dependent on the intensity of the breakdown experience in their socio-material practice.

In summary, rather than seeing forward movement as an outcome of re-constructions of time only (Kaplan \& Orlikowski, 2012), our approach suggest that a successful reconstruction of time can only proceed once actors see how the socio-material relationships of their practice match with the exigencies of that moment. It follows that temporal work will be low once actors experience a mild breakdown in ongoing practices yet substantial if actors face a complete breakdown in the socio-material relationships of their practice.

\section{Method}

We studied temporal work at six agricultural associations all operating regionally in the Eastern part of the Netherlands. These associations usually perform landscape work using subsidies or other public funding but now they are seriously threatened by selective subsidy requirements. Each association draws on a specific a socio-material practice. Some operate in an area with sufficient and diverse natural resources, while others have to cope with resource scarcity and difficult work conditions. There are also variations in the multiplicity of activities, knowledge, equipment, and standards of excellences required to perform good landscape work. Furthermore, some associations experienced with efforts to commercialize their activities in order to lower their dependence on subsidies while others remain faithful to their respective historical values. These variations in socio-material structures allows us to examine how temporal work occurred, its intensity, and the effects in terms of strategic change and practice development.

We use an embedded case study design that combines multiple data sources (Miles \& Huberman, 1994) for a cross case examination of how variations in socio-material structures at the six agricultural associations produce different types of temporal work in the face of farreaching changing funding conditions. Our research involved two and a half years of fieldwork and started in August 2009 until April 2012. Our embedded case study forms a research in a context with a "system-disturbing potential" created by changes in technology, new regulations, laws, or major economic shifts leading to change (Tolbert \& Zucker, 1997:104). Organizations are usually assumed to anticipate such events by announcing the 
adaptation of new practices and technologies, personal changes, in response to upcoming changes (Barley \& Tolbert, 1997). Such an approach demands from researchers the use of a before and after design on the basis of baseline data of an event that will occur. Therefore, we used multiple and distinctive data collection techniques, such as interviews, observations, and archive studies to understand the context, the various socio-material structures at the level of the associations, and subsequent temporal work. We spent a total of 250 hours in the field doing observations on site and participation in cluster meetings. Furthermore, we conducted a total of 24 formal and 20 informal interviews with key informants and members of the associations. In addition, we read about 500 pages of archival materials, meeting minutes, annual reports, newsletters, and governmental policy regulations. We use pseudonyms to safeguard the names of the six agricultural associations: Trim Cutter, Green Care, Coppice Expert, Heathland Preservers, White Spots, and Green Heritage. All of these six nonprofit associations are located in the eastern part of the Netherlands. Below we first elaborate on the background of these agricultural associations followed by a further specification of our data collection and analysis techniques.

\section{Background of agricultural associations and regulatory changes}

In the Netherlands, there are about 200 agricultural associations with a total of about 9000 members: usually farmers but also many volunteers. Most agricultural associations were founded in the 1990s to resolve tensions between groups interested in the natural environment and the agricultural interests of farmers. Nowadays, agricultural associations work on a subsidized basis and perform the work necessary to preserve ecological and cultural value of their local environments in close collaboration with local farmers. Some of these farmers are actively involved in agricultural work through their presence in the work forces for which they receive a payment. Volunteers are mostly local people with an interest in preserving and doing good for their local landscapes. Landscape work may consist of all kinds of activities such as designing new landscape elements, protecting wildlife, maintenance of riverbeds and roadsides, coppicing hedges, but also maintaining larger wooded areas. Most landscape work is financed by national or European subsidies and is in general conceived as serving the public interest. Some associations have managed to lower their reliance on subsidies since they receive income from municipalities and private landowners who pay for the maintenance of 
their private landscape elements. Therefore, it is important for some associations that they maintain a strong local focus as they depend on good relationships with local authorities and landowners to continue in existence. The region called 'de Achterhoek', is well-known for its biodiversity and its unique landscape. However, the ecological conditions in which these association operate varies. Some associations operate in an area that is of significant biodiversity and dense woodlands, while other operate in a less ecologically rich area, with many fallow lands often termed 'white spots'. As a result, some associations developed have multiple activities to conduct landscape work in an area full of bio-diversity whilst others rely on one single activity because that is dictated by the local circumstances. This also applies to the use of equipment. Some associations conduct landscape work using state-of-the-art equipment, unlike others who do the job by hand in a perhaps a less professional manner. Despite differences, all these associations are highly appreciated by local, provincial, and national bodies as they are considered good stewards of the natural environment and also a legitimate spokesman for local agricultural and landscape matters.

Between 2009 and 2012, some of the associations joined an interregional cross-border project between the Netherlands and Germany to explore the opportunities for exploiting biomass materials for heating purposes. This enabled these participating associations to experiment with different practices and ways of earning extra incomes. Unfortunately, this initiative did not live up to the expectations because there was a lack of interest in adopting biomass for hearing in the relevant communities.

In 2012, the Dutch Ministry of Economic Affairs published drastic changes in the subsidy requirements for agricultural landscape maintenance work. These changes drastically contradict with current standards about how best to finance and structure landscape work. The reason why the ministry is declaring the new regulations is that they believe that the cost of bureaucracy can be reduced and competition amongst landscape work organizations encouraged. One of the most important changes is that this Ministry expects that future landscape work must be performed by so-called 'farmer collectives', which are intended to be organizational arrangements able to manage and perform large-scale landscape work. The Ministry is determined to see these changes implemented. A ministerial note states; "Without proper design and implementation, the proposed greening measures will hardly be effective in stimulating farmland biodiversity and reducing greenhouse gas. Their effectiveness would be improved by tailoring them to local conditions and stimulating the realization of 'green infrastructure' through regional coordination"'(PBL note, greening the CAP, 2012). While these requirements are still in development, most associations worry about the impact on 
ongoing practices. To deal with the uncertainties and to anticipate the coming changes, the six associations founded a so-called participation cluster of collaborating agricultural associations, called VALA (original name), in January 2013.

\section{Data collection}

We drew upon three data sources: interviews, documents, and observations to assure a thorough understanding of the impact of the funding changes, socio-material structures, and temporal work. Table 1 summarizes the chronology of our research, including focus areas and methods used in more detail. 


\begin{tabular}{|c|c|c|c|}
\hline Year & $\begin{array}{l}\text { Key phases in the } \\
\text { development of agricultural } \\
\text { associations }\end{array}$ & Research focus area & $\begin{array}{l}\text { Primary data sources and } \\
\text { amount }\end{array}$ \\
\hline $\begin{array}{l}1995- \\
2006\end{array}$ & $\begin{array}{l}\text { Founding of agricultural associations in } \\
\text { 'the Achterhoek' necessary to restore } \\
\text { and preserve the balance between } \\
\text { natural and agricultural interest }\end{array}$ & $\begin{array}{l}\text { Context, understanding } \\
\text { historical development of } \\
\text { each association. }\end{array}$ & \multirow{2}{*}{$\begin{array}{l}\text { (2009) } 8 \text { formal } \\
\text { interviews with key members of each } \\
\text { association ( } 8 \text { hours recorded, } \\
\text { transcribed verbatim) } \\
\text { (2009) } \\
2 \text { expert interviews with } \\
\text { knowledgeable agents (experts of } \\
\text { umbrella organizations) (notes) } \\
\text { (2009) } \\
\text { Archival data (CLM Oerlemans report, } \\
\text { 2004) } \\
\text { (2009 - 2013) Observations on site } \\
\text { and during meetings, workgroups, etc. } \\
\text { (Results presented in table 2) }\end{array}$} \\
\hline $\begin{array}{l}\text { 1999- } \\
2011\end{array}$ & $\begin{array}{l}\text { A stabile subsidy regime enabled the } \\
\text { associations to locally perform } \\
\text { practices and achieve ends } \\
\text { Some association probed in lowering } \\
\text { dependence on subsidies by an } \\
\text { involvement in regional bio-mass } \\
\text { project }\end{array}$ & $\begin{array}{l}\text { Establishing variations in } \\
\text { socio-material structures at } \\
\text { the level of the agricultural } \\
\text { associations. }\end{array}$ & \\
\hline $\begin{array}{l}2012- \\
2013\end{array}$ & $\begin{array}{l}\text { New subsidy and regulatory changes } \\
\text { are announced (GLB) in 2012, yet } \\
\text { rather vague. (clarity expected in 2014). } \\
\text { Increasing concerns about the future. } \\
\text { Association joint cluster association to } \\
\text { reduce and interpret upcoming changes } \\
\text { and consequences to act in a larger } \\
\text { 'farmer collectives'. } \\
\text { Associations identify larger scale } \\
\text { opportunities (biomass energy) to lower } \\
\text { dependency on subsidy regime. }\end{array}$ & $\begin{array}{l}\text { Understanding temporal work } \\
\text { deriving from actors' } \\
\text { engagement in practices in } \\
\text { relation to implications }\end{array}$ & $\begin{array}{l}\text { 2012-2013 Observing board members } \\
\text { of the associations during cluster } \\
\text { meetings ( } 6 \text { meetings) } \\
\text { (2009-2011) } \\
\text { (2012) } 14 \text { formal in-depth interviews } \\
\text { (recorded, } 8 \text { hours) and informal } \\
\text { (notes) interviews to understand the } \\
\text { degree of temporal work at each } \\
\text { association. } \\
\text { (Results presented in table 3) }\end{array}$ \\
\hline
\end{tabular}

Table 1 phases and data collection techniques

First we started collecting data to understand the context and historical background of agricultural associations in general. Consistent with our practice perspective, we start searching for the coherence of socio-material structures underlying each associations practice. We did so by following the suggestions of Sandberg and Tsoukas (2011) to search for the entwinement logic of practice of actors at these associations. Following in-depth interviews and observations on site, we could identify different configurations of the socio-material structures at each association. We specified variations of these configurations in the following terms: historical background, standards of excellence, practice ends pursued, material arrangements such as equipment and knowledge, environmental working conditions, and local embeddednes. We present the findings in Table 2. Finally, we shifted our focus to understand the degree of temporal work on the basis of variations in these socio-material structures in response to the upcoming regulatory changes. For that purpose, we used the guidelines offered by (Sandberg \& Tsoukas, 2011:349) to search for deviations and boundary crossings. 
"Deviations emerge when new discourse items are introduced or new actions appear. Exploring how practitioners respond to deviations enables researchers to see what is significant to practitioners (what matters to them) and, therefore, comes close to grasping the logic underpinning their sociomaterial practice”. 
Standards of excellence (how is good landscape work achieved?

Initially driven by representing farme

an area that has a rich bio-diversity but

dispersed which makes landscape work

farmers and

$100 \%$ depended on

subsidies

\section{Green Care}

100 members, 80 donators.

Subsidy dependence is $35 \%$.

$-40 \%$ and based on

lonstanding contracts.

Strives for continuing landscape by farmers. Explores commercial ends.

Started as a project bureau for organizing communities and other bodies interested in persevering the local cultural value of landscape elements.

Strives for continuity by interest and conducting landscape work in activities conducted for farmers and conducting landscape in commission of

Initially driven by representing farmer interest and conducting landscape work in

\section{Coppice Experts}

About 535 members. Commission driven, less dependent on subsidies.

Only (re-current) projects.

\section{Heathland Preservers}

Dependent on subsidies and donators.

400 members of which most of them volunteers
Strong community driven association mostly driven by volunteers. Heatland Preservers owns some important landscape elements in their operative area which require work has become their cornerstone specialized hand work to maintain. Hand executing re-current projects according to the standards set by their clients.

\section{Strives to conduct landscape}

work in a professional and

efficient manner.

Increasingly pursues

ends.

\section{Strives to remain the leading}

local authority in preserving the

valuable local nature by

involving all kind of

stakeholders (schools,

municipalities, etc.)
Increasingly pursues commercia
Strives to secure income for Initially established to represent the interest of farmers and cultivation of landscape elements. farmers to secure income for

$100 \%$ dependent on subsidies.

150 members (land owners

and farmers)
Landscape work is based on a social and joyful activity performed by many volunteers. Sharing knowledge and show goodwill is important to stay accustomed with the local community
Performing good landscape work is a

matter of coordination of workgroups in the field and regular training and dealing with the tensions that arise with balancing the responsibility between environmental and agricultural matters.

Performing good landscape can only be completed by proper planning and continuity. Accounting and "good" governance by being transparent are considered key values.

Performing good landscape work require continuous development of professional knowledge about landscape work in relation to regulations.

\section{Good landscape work is built on a basic} knowledge of nature (plant material) and dealing with the problems typical for this area
Material arrangements (equipment, environmental circumstances and social relationships.

There are work groups consisting of farmers

working with fairly modern equipment

Average richness of biodiversity (dispersed) and therefore difficult to exploit in a cost effective

way (for instance, as biomass products)

Identity towards local communities is vague due to diverging views internally that persist for a long time.

Work groups work rather independently

because of recurrent projects. The main part of the work is done by hand because work

locations are difficult to reach with heavy professional equipment. There is a mixed biodiversity which require different work practices.

PAN is considered as a leading organization in landscape work and participates in a local pilot project with other local parties.

Work groups (farmers) are used to work with state of the art equipment. These workgroups are familiar with the principles of this association and trained on the job by experts. This area is well-known for its density of forests and landscape elements. The association maintains contacts with local policy makers but also with provincial bodies and legislators. There are workgroups consisting of volunteers (farmers, inhabitants). There is much biodiversity and new sources are attracted regularly. Landscape work requires old fashion handwork and some special equipment is occasionally hired if necessary.

The involvement of local communities (elementary schools, farmers, and the municipality) has a long tradition.

Work groups use fairly modern equipment. The areas consist of many so called white spots (few landscape elements) which constrains efficient work. Profiling the association to bordering municipalities is sometimes complicated and deserves continuous attention. 


\begin{tabular}{|c|c|c|c|c|}
\hline $\begin{array}{l}\text { Green Heritage } \\
\text { Founded in } 1997 . \\
83 \text { members } \\
\text { (majorly dependent on re- } \\
\text { current projects assigned by } \\
\text { municipalities (indirect } \\
\text { subsidy) }\end{array}$ & $\begin{array}{l}\text { Founded as a spin-off of the municipality of } \\
\text { Lichtenvoorde which offered a stabile work } \\
\text { base which still provides a secure income } \\
\text { for this association. Never rally on } \\
\text { maintenance of landscape elements. }\end{array}$ & $\begin{array}{l}\text { Strives for carrying out } \\
\text { sufficient landscape maintenance } \\
\text { work (mainly road sides) and } \\
\text { also authority in respect to } \\
\text { subsidy regulations. }\end{array}$ & $\begin{array}{l}\text { Good landscape work requires a basic } \\
\text { understanding of nature which especially } \\
\text { applies to the work forces but also the } \\
\text { knowledge of changing regulations } \\
\text { necessary to advice farmers. }\end{array}$ & $\begin{array}{l}\text { Work groups use fairly modern equipment. } \\
\text { The area is difficult to maintain because of the } \\
\text { many dispersed elements. } \\
\text { There is a long term relationship with the } \\
\text { municipality as major provider of work but the } \\
\text { association is in favor of intensifying } \\
\text { relationship with farmers for acquiring more } \\
\text { work. }\end{array}$ \\
\hline
\end{tabular}

Table 2. Configurations of the socio-material structure of each agricultural association 
Interviews. We used formal face-to-face interviews to collect rich data from the points of view of key actors. We had expert interviews with leading and visionary people familiar with regulatory changes and the purpose of agricultural associations in general. Furthermore, we interviewed the chairman of the participation cluster (VALA) because of his familiarity with the practices of each association, including their positions in respect to the regulatory changes. This so-called "birds eye" perspective (Birkinshaw, Brannen, \& Tung, 2011), was beneficial as additional data to see how it matched our field observations (on site) and interviews conducted at each association.

We interviewed key informants such as the coordinators and the chairmen of each association. During these interviews, we specifically asked these key informants for the historical development, cornerstones, values and how they became structured and sustained in today's practices (see Gehman et al., 2013). This was necessary to understand how the past persists in today's socio-material structures and is reproduced in today's ongoing practice as practice memory (see Schatzki, 2006). On occasion, we went into the field to observe the environmental conditions in which actual landscape work takes place.

Once our understanding of ongoing practice was sufficiently understood, we turned our focus to the present struggles at these association regarding the upcoming regulator changes. We organized special interview rounds with coordinators and chairmen of the associations. According to Sandberg and Tsoukas (2011), practitioners tend to temporarily step back from their socio-material practices when researchers prompt practitioners to reflect on what they do. "Practice then becomes reflexive insofar as practitioners obtain a clearer view of their actions and, looking back at them, can see aspects they could not see before" (Sandberg \& Tsoukas, 2011:350). By placing practitioners into a mode of deliberation, we were able to capture and document how practitioners revert to socio material relationships when establishing links across the past, present, and future. Our central interview question was: in what way will the upcoming regulatory changes affect ongoing practices and what should be changed in their practice to match the expected future demands? All formal interviews were recorded and transcribed for coding purposes. We elaborate on this in the data analysis section.

Observations. Observations are suitable for understanding micro-processes of strategy work (Whittington, 2006), and to help to search for the entwinement of social and material relationships (Sandberg \& Tsoukas, 2011). We observed everyday work within the associations on a regular basis to understand how practices are embedded in the local context 
and also gained micro-level insights of daily work in organizations (Feldman, 2004; Jarzabkowski, 2005b). We observed the coordinators and chairmen of each association during their presence in cluster meetings and document how they respond to initiatives taken by members of the other associations. These observations helped to reveal what these members consider as significant in their own particular practice (see also Stensaker \& Falkenberg, 2007). It was thus possible to identify temporal work during these cluster meetings in as far key members deliberately reflect on the upcoming changes in relation to their practices and that of others. Finally, the first author attended several workshops, so-called road shows, organized by three of the six associations in early 2009 to promote biomass material as sustainable energy source in the region. During these workshops, he was able to observe how members of agricultural associations are responding to the potential need of adopting new practices

Archival materials. We made use of documents such as agricultural magazines, reports and historical data to improve our understanding of the context. Furthermore, we were included on distribution lists to obtain meeting agendas and minutes. Using a variety of data sources was helpful for triangulation (Eisenhardt, 1989) but also contributed to enriching our understanding of how change unfolds over time at these associations.

Data analysis. Analyzing the data started during our initial field work in which we began to gradually develop knowledge about the core concepts studied as presented in Table 1. Our understanding of the institutional context in which these agricultural associations operate gradually emerged throughout our involvement in the project. Based on the data collection techniques described in the previous section, we developed typographies of the socio-material structures of each association on the basis of the aspects as discussed in the data collection techniques. In addition, we also included key figures of each association in terms of size (total members) and the extent of subsidy reliance. Our findings are presented in Table 2. In the final phase, we started analyzing temporal work in relation to outcomes. The intensity of temporal work was indicated by the degree of breakdown experience of ongoing practice in light of the upcoming changes. Low temporal work indicated that socio-material relationships remained significant to actors. As such, actors remained considering the past, present, and future as coherent. Moderate temporal work is indicated by the persistence of breakdowns in ongoing practice, requiring actors to re-establish links across time to match expected future demands. Substantial temporal work is indicated by a complete breakdown of the socio-material structure. Here, actors encounter significant problems in linking the past, 
present, and future. In Table 3, we present illustrative quotes from the interviews that we categorized into the levels low, moderate, and substantial temporal work.

Finally, we analyzed how the socio-material structures showed up as problematic to the actors in our study in the light of the upcoming changes, and how this influenced the way actors struggle to re-establish links between the past, present, and future. We present these results as case descriptions and cross- analyzed the descriptions of the data in the results section below.

\section{Results}

Our study revealed that differences in socio-material structures at the level of each individual association, produce different levels of temporal work, and also distinct outcomes for strategic change and practice development. We found three different levels of temporal work, namely low, moderate, and substantial. Low temporal work occurred at Green Care and Heathland Preservers. Here we found that low temporal work resulted in a continuation of ongoing practices, and thus no strategic change. We observed moderate temporal work at Coppice Experts and Trim Cutter. This lead to changing strategic orientations and adaptations in ongoing practice. Finally, substantial temporal work occurred at White Spots and Green Heritage because actors faced a complete breakdown in ongoing practice. Below we discuss the case narratives in respect to the different levels of temporal work in relation to the sociomaterial structures of the practices we studied. The key findings are presented in Table 4. 


\begin{tabular}{|c|c|c|}
\hline $\begin{array}{l}\text { Intensity of } \\
\text { temporal work }\end{array}$ & $\begin{array}{l}\text { Links } \\
\text { to: }\end{array}$ & Illustrative examples from the interviews: \\
\hline \multirow{3}{*}{$\begin{array}{l}\text { Low: } \\
\text { (Green Care and } \\
\text { Heathland } \\
\text { Preservers) }\end{array}$} & Past & $\begin{array}{l}\text { "We always knew that being depended on subsidies is a risk, therefore we have always looked and found alternative funding sources" (coordinator Green } \\
\text { Care) } \\
\text { "Workforces are used to directly sell wood material by themselves, for own profit, our association had never benefited from that money. Yet, if subsidies } \\
\text { cease, we might have to change in the future and of course, this will be a source of tensions between us and the workforces" (coordinator Green Care). }\end{array}$ \\
\hline & Present & $\begin{array}{l}\text { "Although we are attentive these changes [in the subsidy requirements], today, there is no sense of urgency in our association yet,....everybody here is } \\
\text { satisfied: board members, workforces, and coordinator" (coordinator Green Care) } \\
\text { "You see, subsidies spend on landscape work serves a public interest for a long time, ...if such interests decline, than our whole sector is in danger but for } \\
\text { now we should focus on our primary task" (coordinator of Green Care) } \\
\text { However, our area is very difficult to maintain for its bio diversity, special areas, and complex structure.... it requires specific knowledge and a good } \\
\text { understanding of local circumstances..... we are a special kind of an association and deeply embedded in the local community....it is difficult for any other } \\
\text { party to do the same" (chairman Heathland Preservers) } \\
\text { "we don't see the need to change right now, we operate in a special landscape and still have a lot of work...nevertheless, we should think about the future", } \\
\text { (coordinator Green Care) } \\
\text { Yes, the GLB [changing subsidy requirement] provides opportunities but nobody knows in which direction exactly.....we don't see it as a problem yet ", } \\
\text { (coordinator Green Care) }\end{array}$ \\
\hline & Future & $\begin{array}{l}\text { "for the future, we are of course too small for doing large scale activities and therefore our current presence in the cluster (VALA) is important for us } \\
\text { "Heathland Preservers"(chairman Heathland Preservers) } \\
\text { "We have to professionalize in the future but also continuing to strengthen our relationship with the community trough intensive collaboration and employing } \\
\text { multiple activities" (chairman Heathland Preservers) } \\
\text { "The idea of exploiting biomass material in the future comes to life" (chairman Heathland Preservers) } \\
\text { "If subsidies decline in future, we have to see how we can charge users for wood to cover the costs..... this might lead to tensions in the future since } \\
\text { workforces who act independently sell the wood material themselves" (coordinator Green Care) }\end{array}$ \\
\hline \multirow{3}{*}{$\begin{array}{l}\text { Moderate: } \\
\text { (Coppice Experts } \\
\text { and Trim Cutter) }\end{array}$} & Past & $\begin{array}{l}\text { "We have always been busy with creating value with wood but it seems that it becomes more valuable these days" (coordinator Trim Cutter) } \\
\text { "Our knowledge of landscape maintenance and subsidy developed in the past becomes even more important for the future" (coordinator Trim Cutter) } \\
\text { "In the past, we have always focused invest in growth by improving knowledge and capabilities involved in landscape maintenance, it is a continues process" } \\
\text { (coordinator Coppice experts) }\end{array}$ \\
\hline & Present & $\begin{array}{l}\text { "If regulations keep on changing, we must commercially exploit biomass....it also serves our workforce members because of increasing labor" (coordinator } \\
\text { Trim Cutter) } \\
\text { "Our power is that we have strong relationships with local farmers as our members but also provincial bodies" (coordinator Trim Cutter) } \\
\text { Today we see that, despite changes in the subsidy requirements, private parties increasingly ask us to do maintenance work of their landscape elements" } \\
\text { (coordinator Coppice Experts) }\end{array}$ \\
\hline & Future & $\begin{array}{l}\text { "In the future, we will increase our focus on private owners for extra income" (coordinator Trim Cutter) } \\
\text { "If the subsidy requirements change so drastically, our future role as a collective becomes even more important because farmers in our area lack to } \\
\text { knowledge of these changes"(coordinator Trim Cutter) } \\
\text { "The future is not so uncertain,...of course, the upcoming changes in the subsidy regime bears on us because we have to invest in revise administration } \\
\text { systems and become busy with that....we have to upscale and standardize ways of working with all the other associations"(coordinator Coppice Experts) }\end{array}$ \\
\hline
\end{tabular}




\begin{tabular}{|c|c|c|}
\hline \multirow{3}{*}{$\begin{array}{l}\text { Substantial: } \\
\text { (White Spots \& } \\
\text { Green Heritage) }\end{array}$} & Past & $\begin{array}{l}\text { "In the past we just focused on helping farmers with subsidies and doing landscape work together with them, this seems to become problematic" (coordinator } \\
\text { White Spots) } \\
\text { "In our area we always had limited possibilities for landscape work...we solely rely funding on one major commission from the municipality for maintenance } \\
\text { of road sides throughout the year" (coordinator Green Heritage) }\end{array}$ \\
\hline & Present & $\begin{array}{l}\text { "we are much younger than most of the other associations and we also operate in an ecologically poor area...[therefore],our existence is really threatened } \\
\text { since our area does not provide so many alternatives for becoming self-sufficient"(coordinator White Spots) } \\
\text { "Currently we are disputing what to do in the future because of this GLB [changing subsidy requirements],..how can we attract money in the future?....older } \\
\text { generation board has no affinity with commercializing....they are difficult to motivate and rather stick to what we always did....nevertheless, we have a few } \\
\text { customers who buy wood chips as biomass or hearth wood from us already there is some movement"(coordinator Green Heritage) } \\
\text { "The board members "new style" are seeing the opportunities and the changes necessary but this is not shared by the older generation of board members } \\
\text { (coordinator Green Heritage) } \\
\text { "Right now, we are really on a pilot flame' because it is uncertain how the GLB [subsidy requirements] regulations affect us........we just operate in a poor } \\
\text { landscape here and that is our challenge and destiny" (coordinator White Spots). } \\
\text { "Networking is important for us, we have to start think in a commercial way, acting on opportunities, collaboration, or even merging with other associations", } \\
\text { (coordinator Green Heritage) }\end{array}$ \\
\hline & Future & $\begin{array}{l}\text { "I see opportunities for our association in the future but only when we operate or merge in a cluster together with other associations" (coordinator White } \\
\text { Spots) } \\
\text { Yes, I see that we must become the central face in this region, as a collective (coordinator Green Heritage) }\end{array}$ \\
\hline
\end{tabular}

Table 3: Three types of temporal work with illustrative quote examples from the study. 


\section{Low temporal work}

Low temporal work occurred at both Green Care and Heathland Preservers. The actors involved expressed how they appreciate their ongoing practice as useful. More specifically, actors of both associations consider their practice as a coherent whole and emphasize the importance of the social material relationships of their practice. For instance, they valued the equipment that they use in relation to the unique but difficult ecological circumstances in which they have to operate. Furthermore, they expressed the importance of the standards of excellence that they had been developed in the past to conduct good landscape work in the present. Actors at both associations also expressed the importance their practice in terms of practice history and tradition. This was particularly observed at Heathland Preservers, the oldest agricultural association in the Netherlands. The chairman of this association appreciates the historical values that belong to traditional landscape work (hand equipment, labor intensive, craftsmanship) and more idealistic values such as working with and socializing with local volunteers rather than working just for payment Because of the value assigned to these traits, they still are carried out in today's practice with pride. Both associations share a strong focus on their local communities (working with volunteers and primary schools), are operating in an area with a high degree of biodiversity, and run multiple activities through which landscape work is performed. Their specialized knowledge about the local circumstances and the application of specialized equipment are also considered as important to sustaining their practice. In other words, despite the fact that actors acknowledge the impact of the subsidy changes for the sector as a whole, it did not unsettle their practice at the moment. Low temporal work implied that links across the past, present, and the immediate future continued to be considered as coherent and acceptable, even when the participants at these associations could to some extent imagine the consequences of these changes for their practice over the long term. For instance, the coordinator of Green Care made clear why future tensions might arise between his association and the workforce about who keeps the profits from selling wood material. Also, the chairman of Heathland Preservers commented that his association is probably too small to deal with all the upcoming changes. Yet, despite recognizing that changes in their practice seems to be unavoidable, their immediate future was not considered to be in danger or at least viewed as problematic and therefore they postponed changes to their practice. For these associations, it was enough to partake in the participation cluster to stay attuned with the expected subsidy changes. In summary, we came to 
understand low temporal work as a form of coping in which actors, despite being sensitive to developments in their context appreciate their practice by emphasizing its significance, rather than questioning the socio-material relationships in relation to what will happen in the future.

\section{Moderate temporal work}

Moderate temporal work occurred at Coppice Experts and Trim Cutter. In these associations, socio-material structures showed up as a theme for both thought and action. In comparison to the previous case, these associations have in common that, since their initiation, their focus was on coppicing landscape elements by using specialist equipment and developing specialized standards. As a result, experience materialized in practice over time. Furthermore, both associations actively participated in a regional project in 2009 the aim of which was to commercialize wood chips for biomass heating. Their supposed role in this project was to become a contractor that delivers competent workforce services for harvesting and producing plant material for biomass technology. Yet there are also some significant differences in the socio-material structures between the two associations. Actors at Coppice Experts maintain many relationships with local farmers and policy makers at a local level as well as provincial bodies, whereas Trim Cutter seemed to be more oriented towards its local community and is particularly driven by farming interests. In addition, Coppice Experts benefits from a rich area of landscape elements whereas Trim Cutter is less fortunate because it operates in an area with scattered landscape elements which complicates efficient landscape work. Yet actors at both associations share the idea that is important to enlarge their scale of operations, improve landscape work in terms of efficiency, and explore the scope for lowering their reliance on subsidies. However, despite the apparent fit between the expected future changes and present efforts to scale up and develop specialized skills, the future changes still imposed on present practice indicating a significant breakdown in ongoing practice. Actors were deliberately attempting to make adjustments to the socio-material relationships, especially in terms of knowledge improvement, defining the necessary standards of excellence, and redefining practice ends such as attaining commercial goals. While doing this, the actors encountered difficulties in the way they deal with current relationships they have with farmers as cooperating members of their associations. Temporal work was moderate because these associations where ahead of themselves by anticipating the need to improve and explore the opportunities, while at the same time exploiting ongoing practice and satisfying their cooperating members and delivering current landscape work contracts. As a consequence, adjustments to the socio-material relationships required ongoing negotiations 
among members and integrative efforts which were considered to be capable of matching future demands. Consequently, temporal work enabled the actors of these associations to link their past with the perceived demands of the future by negotiating change in the present. Therefore, what happens in the present is still considered as important since actors at both associations realize that their core business remains earning an income by delivering good landscape work in their own operating areas largely subsidized by the national government and EU.

\section{Substantial temporal work}

Substantial temporal work by actors was encountered at White Spots and Green Heritage. Here, the upcoming changes had been already unsettling their ongoing practice significantly. Both White Spots and Green Heritage suffer from a lack of biodiversity (so called white spots areas), which complicates efficient larger scale operations. Furthermore, White Spots has since its founding primarily focused on helping farmers with their requests for agricultural subsidies but also offered the same farmers to work for their associations an extra income. In comparison to White Spots, Green Heritage seems to be more advanced in terms of knowledge about biomass technology. In fact, Green Heritage actually serves a few customers with woodchips for their biomass heating installations. However, they are largely constrained by a lack of proper plant material. Green Heritage also suffers from severe internal struggles between the older generation board members who want to continue exploiting a long-standing relationship with their municipality for maintenance of road-sides. In turn, the new board members are much more open for change and exploring alternative practices. Actors at both associations could clearly articulate how the upcoming subsidy requirements will change practices for all agricultural associations. Yet because of the current state of affairs in their own associations, they could hardly envisage how to anticipate effectively on the future. We documented how actors at both associations already struggled with present concerns, let alone meeting the challenge of the upcoming changes. Our analysis revealed that the actors at both associations disapproved the socio-material relationships underlying their practice which reflects a complete breakdown of their practice. Rather than remaining concerned about to deal with the upcoming changes, the socio-material structure of their practices completely loses their significance to them. At White Spots, actors thought that 
they had been focused for too long on local farmers and helping them to earn an extra income by doing work landscape work for the association. As a result, White Spots had become stuck with helping farmers and even if they had the opportunity to do otherwise, they might have faced difficulties in exploring potentially more fruitful activities because of the lack of biodiversity in their operating area. At Green Heritage, the past was relevant because the ideas of the older generation board members imposed on the present acted as a constraint in conjunction with the poor quality of plant material that could have been used for commercial purposes. These tensions were paralyzing the present already and this would only be worsened by the upcoming changes in the subsidy requirements.

Although actors could clearly imagine a future for farmer collectives, they were unable to finds solutions for their own future because they had distanced themselves from ongoing practice. The only solution envisioned by participants at both associations was that they could immediately merge with other more resourceful and professional associations, like the bordering Trim Cutter. However, that was not feasible at the time so further interpretative breakdowns occurred because of the inability of actors to link the future with the past and the present of their practice

\begin{tabular}{|c|c|c|c|c|}
\hline $\begin{array}{l}\text { Level of } \\
\text { temporal } \\
\text { work }\end{array}$ & $\begin{array}{l}\text { Characteristics of the socio- } \\
\text { material structure }\end{array}$ & $\begin{array}{l}\text { Breakdown } \\
\text { experience }\end{array}$ & Temporal work & $\begin{array}{l}\text { Outcome in terms of } \\
\text { practice development }\end{array}$ \\
\hline $\begin{array}{l}\text { Low } \\
\text { temporal } \\
\text { work }\end{array}$ & $\begin{array}{l}\text { Several number of activities to } \\
\text { pursue ends. Operate in an area } \\
\text { with a high degree of bio } \\
\text { diversity and sufficient natural } \\
\text { resources. Maintain a strong } \\
\text { local focus, and are strongly } \\
\text { embedded in local community. }\end{array}$ & $\begin{array}{l}\text { Participants } \\
\text { appreciate aspects of } \\
\text { a practice by } \\
\text { articulating the } \\
\text { coherence and } \\
\text { significance of } \\
\text { practice for the time } \\
\text { being }\end{array}$ & $\begin{array}{l}\text { Not unsettling a } \\
\text { practice: links across } \\
\text { the past, present, and } \\
\text { future remain } \\
\text { coherent because } \\
\text { plausible. }\end{array}$ & $\begin{array}{l}\text { Re-production: } \\
\text { No current changes } \\
\text { necessary as participants } \\
\text { preserve their practice. } \\
\text { Actions are postponed to } \\
\text { the future. }\end{array}$ \\
\hline $\begin{array}{l}\text { Moderate } \\
\text { temporal } \\
\text { work }\end{array}$ & $\begin{array}{l}\text { Few activities (dominantly } \\
\text { large scale coppicing). On } \\
\text { average operate in an area with } \\
\text { abundant landscape elements. } \\
\text { Building on experience and } \\
\text { professional skills. } \\
\text { Community driven but } \\
\text { increasingly also regionally } \\
\text { focused. }\end{array}$ & $\begin{array}{l}\text { Participants call } \\
\text { attention to aspects of } \\
\text { their practice, re- } \\
\text { examining features of } \\
\text { practices and align } \\
\text { them with future } \\
\text { through negotiation. }\end{array}$ & $\begin{array}{l}\text { Links to the past, } \\
\text { present, and future } \\
\text { are attributed to } \\
\text { combine change } \\
\text { efforts in the present } \\
\text { on the basis of } \\
\text { expected future } \\
\text { requirements }\end{array}$ & $\begin{array}{l}\text { Re-alignment: } \\
\text { Participants engage in the } \\
\text { process of adjusting their } \\
\text { practice with regard to } \\
\text { the imagined future but } \\
\text { also remain sensitive for } \\
\text { ongoing practice as they } \\
\text { are considered equally } \\
\text { important }\end{array}$ \\
\hline $\begin{array}{l}\text { Substantial } \\
\text { temporal } \\
\text { work }\end{array}$ & $\begin{array}{l}\text { Mainly focused on one core } \\
\text { activity (by force) because } \\
\text { operating in an area with a } \\
\text { scarcity of landscape elements, } \\
\text { difficult to maintain. Mainly } \\
\text { farmer driven. }\end{array}$ & $\begin{array}{l}\text { Because of further } \\
\text { interpretative break } \\
\text { downs, participants } \\
\text { isolate practice } \\
\text { features as useless } \\
\text { and distance } \\
\text { themselves from } \\
\text { practice. }\end{array}$ & $\begin{array}{l}\text { Links could not be } \\
\text { established between } \\
\text { the future, past and } \\
\text { present. Further } \\
\text { interpretative } \\
\text { breakdowns occurred. }\end{array}$ & $\begin{array}{l}\text { Uprooting: } \\
\text { No change because } \\
\text { paralyzed, only offering } \\
\text { drastic and unrealistic } \\
\text { solutions for the } \\
\text { immediate future. }\end{array}$ \\
\hline
\end{tabular}

Table 4: differences of socio-material structure, breakdowns, level of temporal work, and outcomes 


\section{Discussion and conclusion}

We began this paper by highlighting the importance of understanding temporal work from a socio-material perspective. We asked: how do variations in organizational sociomaterial structures underlying ongoing practice shape different levels of temporal work and what are the implications for strategic change and practice development? Our analysis of the struggles with change at six agricultural associations facing imminent threats showed that different configurations of socio-material structures produced different levels of temporal work with each having distinct outcomes for change. It seemed that a certain consistency and maintenance of historical values, sufficient natural resources and biodiversity, multiple activities in combination with a strong local orientation produced low temporal work. In this case, actors emphasized the significance of the socio-material structures for the time being and, consequently, postponed changes to practices, despite acknowledging the upcoming changes. Moderate temporal work occurred at associations that were attuned to the upcoming changes but faced internal struggles to balance the demands of the future with present practices, which seemingly went well due to ongoing negotiation processes. Remarkably, these associations had been working for years to improve their specialist skills and standards of excellence and, to a certain extent, benefit from working under acceptable working conditions with sufficient natural resources. In analyzing the case, we found that substantial temporal work occurred because these two associations where seemingly too far ahead of themselves in terms of living already in the future, while at the same time encountering problems in ongoing practice. Temporal work was substantial because actors experienced a loss of significance of the socio-material structure underlying their practice. Socio-material relationships were uprooted typically because these associations suffered from insufficient natural resources, board struggles about which strategic direction to pursue, and largely depend on single activities and feel bounded by past decisions. Hence, actors failed to establish coherent links between the future, present and the past, despite their ability to propose drastic solutions.

Our study showed that understanding the outcomes we observed is incomplete without incorporating how actors are embedded in various socio-material structures. Moreover, our research strongly indicates that the level of temporal work is shaped by a breakdown of these structures, rather than a breakdown of only understandings. In other words, it is not just the past, present, and future that are subject of deliberation but also the socio material relationship in their practice when they break down. This study indicates how agency is shaped by the 
structuring contexts in which actors are embedded. Following Emirbayer and Mische (1998) threefold structure of agency (composed of the past, present, and future), we showed how these structuring context in which actors are embedded -understood as socio-material structures- inform the 'practical evaluative' ability of actors to re-iterate the past, and reimagining the future in the face of an uncertain present. Moreover, our study showed how various configurations of these socio-material structures and different levels of temporal work can be related to the dominant temporal orientations of actors. For instance, actors were dominantly engaged in the past in the case of low temporal work. In this case, actors relied heavily on their practice history when making sense of the future. In case of substantial temporal work, actors were dominantly engaged in the present and encountered difficulties in making sense of the past in relation to the future, which in essence, lead to further interpretative breakdowns. Moderate temporal work implied that actors were already reimagining their future and ahead of themselves without disbanding the past and present responsibilities. However, it is difficult to pinpoint if the different levels of temporal work are shaped by of actors' dominant temporal orientations and how they related to the socialmaterial structures. However, our results may give reason to think of temporal work as radiating within one dominant temporal orientation since all temporal orientations have subtones of the other two (Emirbayer \& Mische, 1998). Stated differently, temporal work reflects the practical 'evaluative ability' of actors to decontextualize their embedded positions and chose alternative routes of actions but its level of intensity may vary with the dominant temporal orientations. The dominant orientations of actors, in turn, are to a large extent shaped by the socio-material structure of a practice. Nevertheless, these kind of rigidities and clear demarcations of sub-tones and dominant orientations are difficult to grasp empirically.

Thus, than presenting our work as an exhaustive set of possible outcomes, our study offer opportunities and challenges for future research. Below we briefly reflect on a view of these opportunities and challenges.

\section{Implications for research}

Our research sheds a new light on the "praxis" of strategy making, with "praxis" defined as "all the various activities involved in the deliberate formulation and implementation of strategy" (Whittington, 2006:619). Our study showed how the efforts of actors to engage in deliberate strategy formulation are shaped by breakdowns in ongoing 
socio-material practices. Although scholars have previously argued that strategy praxis is something that actors "do", our research suggests that strategy praxis derives from a more fundamental way of their involvement in ongoing socio-material practices. It is the reflections on these practices that forms the input for deliberative and future-oriented actions (see also Chia \& Holt, 2006). Indeed, Vaara and Whittington (2012) also suggest shifting focus to emergence rather than deliberate strategy planning as point of departure. In this sense, we also complement studies that are interested in strategic sense-making (Balogun \& Johnson, 2004; Gioia \& Thomas, 1996). Sensemaking occurs when actors encounter a breach in what they expect and what they experience (Louis, 1980). According to (Weick, 2012), sensemaking is confined to interruptions, anomalies, and the unexpected and there must be considered as an episodic processes. As Weick notes; "In the language of Heidegger, sensemaking is triggered when the availableness of ready-to-hand coping is interrupted and attention shifts to unreadyto-hand occurentness. The interrupted project still provides a frame and restoration occurs within that frame" (Weick, 2012:146). We show that that socio-material relationships are part of sensemaking processes as they show up when actors encounter a breach. In other words, aspects of practices are only discovered in the breach (Suchman, 1987).

Our study also contributes to the organizational change literature, and particularly those studies concerned with examining the antecedents of radical change from an organizational perspective (Greenwood \& Hinings, 1996). The organizational change literature is mainly occupied with studying change projects once developed into recognizable forms. Yet recently, Smets, Morris, and Greenwood (2012) have reported that institutional change begins with the level of practice, rather than through external shocks, field contradictions, or intra-organizational dynamics. In a similar vein, Lounsbury and Crumley (2007) examined how new practices are developed unintentionally. We contribute to this stream of literature by shedding a light on which circumstances actors engage in changing practices previously not attained, but also why actors chose to maintain their practice, adopt new ones and combine it with existing practice, or even abandoned their practice in the face of changing environmental conditions.

The interest for human agency and the transformation of fields has also attracted scholars of institutional entrepreneurship (Dorado, 2005; Lawrence et al., 2011) for instance, Dorado (2005) argues that field level characteristics in terms of degree of multiplicity and institutionalization (Zucker, 1977), shape actors' logic of actions in terms of strategic (future), sensemaking (present), or a routine (past) orientation. Our study suggests that such orientations are shaped by the socio-material structure of their organizational practices, rather 
than through field characteristics. For instance, the nonprofit associations we studied each draw on a different temporal orientation, despite being parts of a common institutional field. This observation would challenge the idea that actors draw on one dominant institutional logic in a given field.

\section{Concluding remarks}

Our perspective on temporal work approached from a socio-material perspective extends approaches that take temporality, emergence, agency, and embeddednes in strategy research seriously. We have developed a socio-material practice perspective on temporal work that reveal how actors' interpretations about the past, present, and future are inherently a part of socio-material structures underlying their practice and that also become subject for change when it breaks down. On the basis of a case with a system-disturbing potential (Barley $\&$ Tolbert, 1997), we observed how breakdowns of practices at six nonprofits occurred as a result of anticipated drastic regulatory changes.

An important reason to study temporal work in long-standing agricultural associations in an institutionalized setting is because in contexts, actors may have taken the socio-material structures for granted. Nevertheless, for future research, it would be interesting to examine how temporal work occurs in new settings in which new socio-material relationships are about to be developed, and thus appear more fragile and emerging. In emerging fields, actors probably deal with varying pasts and uncertain futures, giving rise to the idea that temporal work occurs sooner, and perhaps, more frequently. Assuming that temporal work is constitutive to organizing, and a practice in itself (Kaplan \& Orlikowski, 2013), future research may thus further specify how temporal work leads to the emergence, maintenance, and change of socio-material structures underlying practices.

Finally, our extension of temporal work demonstrates the value of injecting a stronger dose of socio-materiality into current practice research. New practice development and strategic change are about actors re-orientations of the past and the future in the face of present exigencies but these re-orientations cannot be separated from their involvement in everyday socio-material practices. 


\section{References:}

Balogun, J., Jacobs, C., Jarzabkowski, P., Mantere, S., \& Vaara, E. 2013. Placing Strategy Discourse in Context: Sociomateriality, Sensemaking and Power. Journal of Management Studies.

Balogun, J., \& Johnson, G. 2004. Organizational restructuring and middle manager sensemaking. The Academy of Management Journal: 523-549.

Barley, S. R., \& Tolbert, P. S. 1997. Institutionalization and structuration: Studying the links between action and institution. Articles \& Papers: 130.

Bourdieu, P. 1990. The logic of practice: Stanford Univ Pr.

Callon, M. 1986. Some elements of a sociology of translation: domestication of the scallops and the fishermen of St Brieuc Bay. Power, action and belief: A new sociology of knowledge, 32: 196-233.

Carlile, P. R., Nicolini, D., Langley, A., \& Tsoukas, H. 2013. How Matter Matters: Objects, Artifacts, and Materiality in Organization Studies: Oxford University Press.

Chia, R. 2004. Strategy-as-practice: Reflections on the research agenda. European Management Review, 1(1): 29-34.

Chia, R., \& Holt, R. 2006. Strategy as practical coping: a Heideggerian perspective. Organization Studies, 27(5): 635.

Chia, R., \& MacKay, B. 2007. Post-processual challenges for the emerging strategy-aspractice perspective: Discovering strategy in the logic of practice. Human Relations, 60(1): 217-242.

Dorado, S. 2005. Institutional entrepreneurship, partaking, and convening. Organization Studies, 26(3): 385.

Dreyfus, H. L. 1991. Being-in-the-world: A commentary on Heidegger's Being and Time, Division I: The MIT Press.

Emirbayer, M., \& Mische, A. 1998. What is agency? American Journal of Sociology, 103(4): 962-1023.

Ericson, M. 2013. On the dynamics of fluidity and open-endedness of strategy process toward a strategy-as-practicing conceptualization. Scandinavian Journal of Management.

Feldman, M. S. 2004. Resources in emerging structures and processes of change. Organization Science, 15(3): 295-309.

Garud, R., Kumaraswamy, A., \& Karnøe, P. 2010. Path dependence or path creation? Journal of Management Studies, 47(4): 760-774. 
Gavetti, G., \& Levinthal, D. 2000. Looking forward and looking backward: Cognitive and experiential search. Administrative science quarterly, 45(1): 113-137.

Gehman, J., Treviño, L. K., \& Garud, R. 2013. Values work: A process study of the emergence and performance of organizational values practices. Academy of Management Journal, 56(1): 84-112.

Giddens, A. 1984. The constitution of society: Outline of the theory of structure: University of California Press, Berkeley, CA.

Gioia, D. A., \& Thomas, J. B. 1996. Identity, image, and issue interpretation: Sensemaking during strategic change in academia. Administrative science quarterly: 370-403.

Greenwood, R., \& Hinings, C. R. 1996. Understanding Radical Organizational Change: Bringing together the Old and the New Institutionalism. The Academy of Management Review, 21(4): 1022-1054.

Heidegger, M. 1962. Being and time (J. Macquarrie \& E. Robinson, trans.): New York: Harper \& Row.

Jarzabkowski, P. 2005. Strategy as practice: Sage.

Kaplan, S. 2008. Framing contests: Strategy making under uncertainty. Organization Science, 19(5): 729-752.

Kaplan, S., \& Orlikowski, W. 2013. Temporal Work in Strategy Making. Forthcoming in Organization Science.

Latour, B. 2005. Reassembling the social: An introduction to actor-network-theory: Oxford University Press, USA.

Law, J. 1994. Organizing modernity: Blackwell Oxford, UK.

Lawrence, T., Suddaby, R., \& Leca, B. 2011. Institutional work: Refocusing institutional studies of organization. Journal of Management Inquiry, 20(1): 52-58.

Louis, M. R. 1980. Surprise and Sense Making: What Newcomers Experience in Entering Unfamiliar Organizational Settings. Administrative Science Quarterly, 25(2): 226251.

Lounsbury, M., \& Crumley, E. T. 2007. New practice creation: An institutional perspective on innovation. Organization Studies, 28(7): 993-1012.

Miles, M. B., \& Huberman, A. M. 1994. Qualitative data analysis: An expanded sourcebook: SAGE publications, Inc.

Orlikowski, W., \& Yates, J. 2002. It's about time: Temporal structuring in organizations. Organization Science, 13(6): 684-700. 
Orlikowski, W. J. 2007. Sociomaterial practices: Exploring technology at work. Organization Studies, 28(9): 1435-1448.

Orlikowski, W. J., \& Scott, S. V. 2009. 10 Sociomateriality: Challenging the Separation of Technology, Work and Organization.

Patriotta, G. 2003. Organizational Knowledge in the making: How firms create, use, and institutionalize knowledge. Editorial Oxford university Press. New york.

Pickering, A. 1993. The mangle of practice: Agency and emergence in the sociology of science. American Journal of Sociology: 559-589.

Reckwitz, A. 2002. Toward a theory of social practices. European journal of social theory, 5(2): 243-263.

Sandberg, J., \& Dall'Alba, G. 2009. Returning to practice anew: A life-world perspective. Organization Studies, 30(12): 1349.

Sandberg, J., \& Tsoukas, H. 2011. Grasping the logic of practice: Theorizing through practical rationality. The Academy of Management Review (AMR), 36(2): 338-360.

Schatzki, T. R., Knorr-Cetina, K., \& Von Savigny, E. 2001. The practice turn in contemporary theory: Psychology Press.

Smets, M., Morris, T., \& Greenwood, R. 2012. From Practice to Field: A Multilevel Model of Practice-Driven Institutional Change. Academy of Management Journal, 55(4): 877904.

Stensaker, I., \& Falkenberg, J. 2007. Making sense of different responses to corporate change. Human Relations, 60(1): 137-177.

Suchman, L. A. 1987. Plans and situated actions: the problem of human-machine communication: Cambridge university press.

Swidler, A. 2001. What anchors cultural practices. The practice turn in contemporary theory: 74-92.

Vaara, E., \& Whittington, R. 2012. Strategy-as-practice: taking social practices seriously. The Academy of Management Annals, 6(1): 285-336.

Weick, K. 1995. Sensemaking in organizations: Sage Publications, Inc.

Weick, K. E. 1979. The social psychology of organizing.

Weick, K. E. 2012. Organized sensemaking: A commentary on processes of interpretive work. Human Relations, 65(1): 141-153.

Weick, K. E., \& Roberts, K. H. 1993. Collective Mind in Organizations: Heedful Interrelating on Flight Decks. Administrative science quarterly, 38(3): 357-381. 
Weick, K. E., Sutcliffe, K. M., \& Obstfeld, D. 2008. Organizing for high reliability: Processes of collective mindfulness. Crisis management, 3: 81-123.

Whittington, R. 1996. Strategy as practice. Long Range Planning, 29(5): 731-735.

Whittington, R. 2006. Completing the practice turn in strategy research. Organization Studies, 27(5): 613.

Wittgenstein, L. 2010. Philosophical investigations: Wiley-Blackwell.

Yanow, D., \& Tsoukas, H. 2009. What is Reflection-In-Action? A Phenomenological Account. Journal of management studies, 46(8): 1339-1364.

Zucker, L. G. 1977. The role of institutionalization in cultural persistence. American Sociological Review, 42(5): 726-743. 